\title{
Validation of nucleolar protein 4 as a novel methylated tumor suppressor gene in head and neck cancer
}

\author{
SEMRA DEMOKAN $^{1,2}$, ALICE Y. CHUANG ${ }^{3}$, KAVITA M. PATTANI $^{2}$, \\ DAVID SIDRANSKY ${ }^{2}$, WAYNE KOCH ${ }^{2}$ and JOSEPH A. CALIFANO ${ }^{2,4}$ \\ ${ }^{1}$ Department of Basic Oncology, Oncology Institute, Istanbul University, Capa, Istanbul 34093, Turkey; \\ Departments of ${ }^{2}$ Otolaryngology-Head and Neck Surgery and ${ }^{3}$ Dermatology, Johns Hopkins University, \\ School of Medicine, Baltimore; ${ }^{4}$ Milton J. Dance Head and Neck Center, \\ Greater Baltimore Medical Center, Baltimore, MD, USA
}

Received October 30, 2013; Accepted November 27, 2013

DOI: 10.3892/or.2013.2927

\begin{abstract}
Methylation of $\mathrm{CpG}$ islands in the promoter region of genes acts as a significant mechanism of epigenetic gene silencing in head and neck cancer. In the present study, we assessed the association of epigenetic alterations of a panel of 12 genes [nucleolar protein 4 (NOL4), iroquois homeobox 1 (IRX1), SLC5A8, LRRC3B, FUSSEL18, EBF3, GBX2, HMX2, SEPT 9, ALX3, SOCS3 and LHX6] with head and neck squamous cell carcinoma (HNSCC) via a candidate gene approach. After the initial screening of methylated $\mathrm{CpG}$ islands on the promoter regions by bisulfite sequencing using salivary rinse samples, only two genes had methylated $\mathrm{CpG}$ dinucleotides on their promoter regions in tumor samples and absence of methylated $\mathrm{CpGs}$ were found in normal salivary rinse samples after bisulfite modification and bisulfite sequencing. We then performed real-time quantitative methylation-specific PCR (QMSP) on 16 salivary rinse and 14 normal mucosal samples from healthy subjects and $33 \mathrm{HNSCC}$ tumor samples for the two genes selected. After validation with QMSP, one gene, NOL4, was highly methylated (91\%) in tumor samples and unmethylated in normal salivary rinses and minimally methylated in normal mucosal samples demonstrating cancer-specific methylation in HNSCC tissues. Although the IRXI gene was observed as methylated in normal mucosal and salivary rinse samples, the methylation values of these normal samples were very low $(<10 \%)$. In conclusion, we identified NOL 4 as a highly specific promoter methylated gene associated with HNSCC. IRXI may have potential as a biomarker for HNSCC and should be assessed in a larger cohort.
\end{abstract}

Correspondence to: Dr Semra Demokan, Department of Basic Oncology, Oncology Institute, Istanbul University, Capa, Istanbul 34093, Turkey

E-mail: demokan@istanbul.edu.tr

Key words: nucleolar protein 4, methylation, head and neck cancer, candidate gene approach

\section{Introduction}

Head and neck cancer, which is the sixth most common cancer in the world among human malignant disorders, is an aggressive and life-threatening disease with poor prognosis, morbidity and high mortality in advanced disease. Survival rates have not improved significantly for patients with head and neck squamous cell carcinoma (HNSCC) in the past 30 years despite active clinical and basic research addressing this issue. More than 40,000 new cases of HNSCC are diagnosed in the United States each year, with a mortality rate of 12,000 in the USA annually (1). Treatment for HNSCC includes surgical resection, chemotherapy and radiation therapy; however, approximately $50 \%$ of all patients have advanced disease at the time of diagnosis often requiring use of all three treatment modalities. Cancer-specific molecular biomarkers, which have the ability to warn the clinicians in the earlier stage before the disease advances, or to provide insight regarding the prognosis of the disease or outcome of the patients, are required. In addition, it is important to develop new methods that provide sensitive and reliable biomarkers of HNSCC for detection, treatment response and prognosis.

Epigenetic alterations are a recent attractive phenomenon of human cancer, with the activation of proto-oncogenes and inactivation of tumor suppressor genes, either through hypomethylation or hypermethylation in the promoter regions of the genes, respectively (2). Transcriptional silencing of tumor suppressor genes by means of promoter hypermethylation plays an important role in head and neck carcinogenesis (3). Methylation of the $\mathrm{CpG}$ islands in the promoter regions of tumor suppressor genes is frequently observed with reduced gene expression $(4,5)$.

From a previous study using the gene expression profiling via oligonucleotide microarray-based approach to discover the new cancer-specific methylated genes (6), in the present study, we evaluated the hypermethylation of 10 genes [nucleolar protein 4 (NOL4), iroquois homeobox 1 (IRX1), sodiumcoupled monocarboxylate transporter 1 ( $S L C 5 A 8)$, leucine rich repeat containing 3B $(L R R C 3 B)$, functional smad-suppressing element on chromosome 18 (FUSSEL18), early B-cell factor 3 (EBF3), gastrulation brain homeobox 2 (GBX2), H6 family 
homeobox 2 (HMX2), septin 9 (SEPT9), ALX homeobox 3 (ALX3)] identified by Restriction Landmark Genomic Scanning (RLGS) in previous studies $(7,8)$, and by personal communication with Bennett et al $(7,8)$, and two other genes [suppressor of cytokine signaling 3 (SOCS3) and LIM homeobox 6 (LHX6)] selected from the literature via candidate gene approach (9-14). IRX1, SLC5A8, FUSSEL18, EBF3, GBX2, HMX2, SEPT9 and $A L X 3$ genes showed tumor suppressor activity in previous cancer studies (15-19) and were involved in transforming growth factor (TGF) signaling pathway which has a high frequency of alteration in HNSCC (15,20-23). To measure methylation levels, real-time quantitative methylation-specific PCR (QMSP) was performed to provide an objective, robust and rapid assessment of promoter methylation status (24-27).

\section{Materials and methods}

Tissue samples. Following institutional review board approval and after obtaining appropriate informed consent, the HNSCC patients and control population from healthy subjects enrolled in a community screening study were recruited from the Johns Hopkins School of Medicine, Department of OtolaryngologyHead and Neck Surgery. Mucosal samples and salivary rinses from healthy population and HNSCC tissue samples were collected. In the present study, salivary rinses were obtained by brushing oral cavity and oropharyngeal surfaces with an exfoliating brush followed by rinse and gargle with $20 \mathrm{ml}$ normal saline solution. The brush was gently agitated to release the obtained material into saline. After centrifugation, the supernatant was discarded and DNA was isolated from the pellet. Tumors were snap frozen and microdissected on a cryostat to $\geq 75 \%$ purity. DNA from 16 salivary rinse samples from noncancer individuals were analyzed as a control, to investigate the normal promoter methylation status of two newly identified candidate genes, IRXI and NOL4. The methylation status of these genes was analyzed in 33 fresh tumor samples from patients with head and neck cancer and 14 normal mucosa samples from healthy individuals.

DNA extraction and bisulfite treatment. DNA was isolated as previously described (28). In brief, DNA was obtained by phenol/chloroform extraction after overnight incubation with proteinase $\mathrm{K}$ (Boehringer-Mannheim, Germany) at $48^{\circ} \mathrm{C}$. DNA from tumor and control samples was subjected to bisulfite treatment using EpiTect Bisulfite modification kit (Qiagen, Valencia, CA, USA) as per the manufacturer's protocol.

Bisulfite sequencing. The bisulfite sequence analysis was performed to determine the methylation status in the promoter regions of 12 genes. Bisulfite-treated DNA was amplified for the 5' region that included at least a portion of the $\mathrm{CpG}$ island within 1-2 $\mathrm{kb}$ of the first exon of the genes. The promoter regions of the genes were found from the database of the University of California, Santa Cruz (UCSC) (http:// genome.ucsc.edu/). Primer sequences were determined by MethPrimer program (29) showing the $\mathrm{CpG}$ islands in the promoter regions of 12 genes for bisulfite sequencing (Table I). A thousand base pair region of the genes' promoters and some part of the first exon were sequenced by the specific primers producing 400-500 bp PCR fragments. The primers for bisulfite sequencing were designed to hybridize to regions in the promoter without $\mathrm{CpG}$ dinucleotides. PCR products were gel-purified using the QIAquick Gel Extraction kit (Qiagen) according to the manufacturer's instructions. Each amplified DNA sample was sequenced by the Applied Biosystems 3700 DNA Analyzer using nested, forward or reverse primers and BD terminator dye (Applied Biosystems, Foster City, CA, USA).

Quantitative methylation-specific PCR. Primer and probe sequences were determined by MethPrimer program showing the $\mathrm{CpG}$ islands in the promoter regions of two genes selected after bisulfite sequencing (Table II). To determine if the methylated genes in tumor samples were cancer-specific, we investigated promoter methylation in 16 normal saliva, 14 age-matched normal mucosa from healthy individuals that were analyzed as a control, to investigate the normal promoter methylation status of two newly identified candidate genes (NOL4, IRX1) and in 33 HNSCC tumor samples by QMSP. Lymphocytes obtained from a healthy individual were in vitro methylated using excess SssI methyltransferase (New England Biolabs Inc., Beverly, MA, USA) to generate completely methylated DNA that was used as a positive control standard. To quantitate the relative percent of methylation, we computed the ratio between the QMSP values of the gene of interest relative to an internal control, ACTB (gene of interest/ reference gene x100) (30). Fluorogenic PCR was carried out in a reaction volume of $20 \mu \mathrm{l}$ consisting of $600 \mathrm{nM}$ of each primer; $200 \mathrm{nM}$ of probe; $0.6 \mathrm{U}$ of platinum Taq polymerase (Invitrogen, Carlsbad, CA, USA); $200 \mu \mathrm{M}$ of each dATP, dCTP, dGTP and dTTP; 1X ROX Dye reference and $1 \mathrm{X}$ buffer [16.6 mM of ammonium sulfate; $67 \mathrm{mM}$ of Trizma (Sigma, St. Louis, MO, USA); $6.7 \mathrm{mM}$ of magnesium chloride; $10 \mathrm{mM}$ of mercaptoethanol and $0.1 \%$ dimethylsulfoxide]. Thirty nanograms of bisulfite treated DNA were used in each real-time QMSP reaction. Amplifications were carried out in 384-well plates in a 7900 Sequence Detector system (Perkin-Elmer Applied Biosystems, Norwalk, CT, USA) and were analyzed by SDS 2.3 (sequence detector system) (Applied Biosystems). Each reaction was performed in triplicate.

\section{Results}

Clinicopathological characteristics of control subjects and patients with HNSCC. Table III describes the demographic parameters of the sample populations used in the present study. The mean age of normal mucosal samples was 43.4 years (range, 24-65). Tobacco users were observed as $42 \%$. Both normal mucosal and tumor samples had a similar male and Caucasian predominance. Smoking rate was $78 \%$ and alcohol consumption was $69 \%$. Tumor samples $(n=33)$ were obtained from patients with stage I (7.4\%), stage II (22\%), stage III (26\%) and stage IV (44\%) lesions. These were from primary tumors of the oral cavity $(n=9)$, oropharynx $(n=7)$, hypopharynx $(n=2)$, larynx $(n=8)$, maxillary sinus $(n=2)$, nasal floor $(n=1)$, salivary gland $(n=1)$ and unknown primary/neck $(n=3)$. The male and Caucasian prevalence was smaller in the normal salivary rinse samples and tobacco users were found as $31.25 \%$. The ages of individuals from which the normal salivary rinse was obtained were slightly lower than the population of head and neck cancer 
Table I. Primer sequences of 12 selected genes for bisulfite sequencing.

\begin{tabular}{|c|c|c|}
\hline Gene name & 5' Primer sequence & 3' Primer sequence \\
\hline \multirow[t]{3}{*}{$L R R C 3 B$} & TAAAGAGAGGGGAAAGATTTTTGTT & ААТСААТТТССССТАСААТТСТАААА \\
\hline & GGAAAATTGAATTTTATTTTTTTT & AАAАТАTТААСТСССТСТАСТАСТСТС \\
\hline & AATAGGAGAAAGAATGGGGTTATAGTT & TAACСТТАСАAАAАAАACAAACAAAA \\
\hline \multirow[t]{4}{*}{ NOL4 } & GGAAGTTTTGAATGGAGTAATTGTT & CAAATACATTTTAАATAАATTCCAАCC \\
\hline & GTTTGGGGTATTATAATTTATTTTGTAGAA & СТСТССТТССТССТАААТССТАСТТ \\
\hline & TAGGATTTAGGAGGAAGGAGAGATT & ACACCATTCTAACCCAAAAAAACTA \\
\hline & GTTGGGATGGTTTTGGTTATAAA & САССТАТТСАСССТАААСТСАТАААА \\
\hline \multirow[t]{2}{*}{ FUSSEL18 } & TTATTTAATTATTTGAGATTAGAATTA & ААТАААТТССТААААААССТААААССТТАТ \\
\hline & GGTTTTAGGTTTTTTAGGAATTTAT & TCACСТАACССАССТАATTAАATTTAA \\
\hline \multirow[t]{3}{*}{$E B F 3$} & TTTTAGGATAAGTTGTAGTTTTTTGTATTT & ATTTAАССССТТААТАССТСССТАС \\
\hline & GTAGGGAGGTATTAAGGGGTTAAAT & САСААААСТСААСССТСТСТССС \\
\hline & GGGAGAGAGGGTTGAGTTTTGTG & CССАAАCATAАAАACТАСТАAC \\
\hline \multirow[t]{3}{*}{$G B X 2$} & GAGGGGTAGGATTTTGTTTTTAATT & AАССТТААААСССТАСААССТТАТС \\
\hline & GAGGTTAGTTTGGGTGGAAAG & ATAAAACATAAACATAAAATAACC \\
\hline & GGTAGGTAAAATGTGAATGAGAAAGAGGAG & ATAAAACATAAACATAAAATAACC \\
\hline \multirow[t]{2}{*}{$\operatorname{IRX} 1$} & TGGGTGAAGAGAAAGTTTTTTTT & AAACATCTTTAACAAAAATACACCC \\
\hline & TTTTGTTAAAGATGTTTTTTGGAGG & TACTTTAATTAACATCCССТTAАAC \\
\hline \multirow[t]{4}{*}{$H M X 2$} & GTTTTGTTATTAGTTTTTTATTTTTTTT & ААССТСАТСССТАТСАСАААТТСТА \\
\hline & GGAATTTGAATTTAGATTTTTTG & TТАААССССТТАААСССТТСТСТ \\
\hline & GAGAGAAGGGTTTAAGGGGTTTA & TACAACAAACAAACAATAAAAAAAA \\
\hline & GGAGGATGGTGGAGTAGTTTGTATA & TCTAACCAAAAACAACCAAAACTAAA \\
\hline \multirow[t]{3}{*}{ SLC5A8 } & GTGGATTGTTTATTTAGGATTAGATGG & AАCСТTCATATAACACATACATACTTAACA \\
\hline & GTGTTAAGTATGTATGTGTTATATGAAGGT & АААААСТААААССТССААСТАСТТСС \\
\hline & GATTGTTGAATTGGAAAGTTAAAATTTA & ССТСАААСССАААТАТААААССТС \\
\hline \multirow[t]{3}{*}{ SEPT9 } & GGAAGATGTTTTTTTTGTTAAGGAG & TCAATCTATACTACТССССААААСC \\
\hline & TTGGGGAGTAGTATAGATTGAAAAGT & TTAАACTTCACСТCAАAАATTCATT \\
\hline & GGATGAATAGTGGGGAATAGTATTG & ССААААААААСССТААААААТСАС \\
\hline \multirow[t]{3}{*}{$A L X 3$} & GTGGGTTTTTAGATATTTGGGTTATT & CAAACAAACAAACCTTAAACTACAATTT \\
\hline & ATTTTTAATAGTTTTTTTTATTGTG & СТААСТТААТАСТААААССАТССАС \\
\hline & TTTGAGTTGTTTGGGATTGG & СТСТААААААТААААСТССАААААСС \\
\hline \multirow[t]{3}{*}{ SOCS3 } & GAGAGTATTTGGTTTAATTTATA & СТТССССТТССССТТТТССС \\
\hline & TGTAGTTTTGGGTTTTTTTTT & СААСТTСТСАТТСАСАТТТСС \\
\hline & GATTTGGATTTTTTGTTT & СТССТССТТССТАССТААТС \\
\hline \multirow[t]{5}{*}{ LHX6 } & GTAGATGGTATGGTTATGGGT & АССТСССТААСТАСТАСС \\
\hline & AGGAGGATAAGGAGGAGGGAG & СТСАТАСТТССААТАСАТАААСС \\
\hline & GTTTTTGTAGTAGTTTTTGT & CCAACATTTACATAATATATTCC \\
\hline & GGTTTATGTATTGGAAGTATGAG & AAAAAAAAACACССТССАACC \\
\hline & GGTTGGAGGGTGTTTTTTTTT & AАТTTTTTCTCTCTССАСС \\
\hline
\end{tabular}

$L R R C 3 B$, leucine rich repeat containing 3B; NOL4, nucleolar protein 4; FUSSEL18, functional smad-suppressing element on chromosome 18; $E B F 3$, early B-cell factor 3; GBX2, gastrulation brain homeobox 2; IRX1, iroquois homeobox 1; HMX2, H6 family homeobox 2; SLC5A8, sodiumcoupled monocarboxylate transporter 1; SEPT9, septin 9; ALX3, ALX homeobox 3; SOCS3, suppressor of cytokine signaling 3; LHX6, LIM homeobox 6 .

patients, mean ages 53.06 years (range, 33-83) and 61.4 years (range, 36-88), respectively. Due to our small cohort, we did not perform any statistics between the clinical parameters and QMSP results of tumor and normal populations.
Genes specifically methylated in HNSCC tumors. In the present study, we investigated methylation of the 12 gene promoters by bisulfite modification and QMSP. In the initial screening of the methylated $\mathrm{CpG}$ islands, bisulfite 

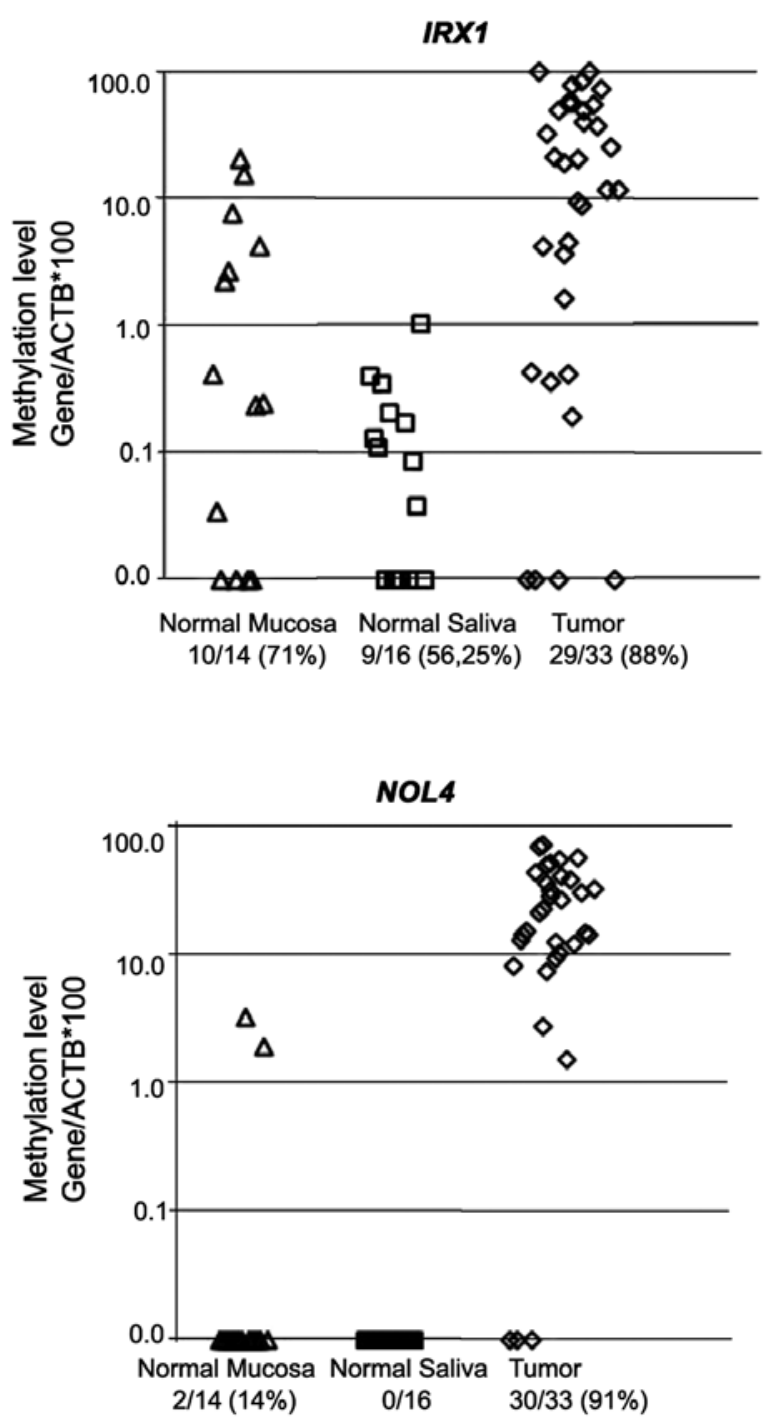

Figure 1. Methylation frequency of two candidate genes IRXI and NOL4 in HNSCC tumors, normal mucosal and salivary rinse samples. Scatter plots of QMSP analysis of candidate gene promoters. $\mathrm{NOL4}$, nucleolar protein 4; $I R X 1$, iroquois homeobox 1; HNSCC, head and neck squamous cell carcinoma; QMSP, real-time quantitative methylation-specific PCR.

sequencing was performed by using four HNSCC cell lines (JHU-06, JHU-022, JHU-022B and JHU-028), eight normal salivary rinses and eight HNSCC samples. Only two genes, NOL4 (NM_003787) and IRXI (NM_024337) (http://www. genenames.org), had methylated $\mathrm{CpG}$ dinucleotides on their promoter regions in tumor samples but absence of methylated CpGs was found in normal salivary rinse samples (Table IV). We investigated the methylation frequency in a larger cohort of normal salivary rinses, mucosal and HNSCC specimens, in order to find a biomarker candidate.

In the second stage of the present study, we performed QMSP on 16 normal salivary rinse and 14 normal mucosal samples from healthy individuals and 33 HNSCC tumor samples for two selected genes. The NOL4 gene showed no methylation (0/16) in normal salivary rinses and two out of 14 (14\%) mucosal samples were minimally methylated between 1 and $3 \%$ methylation values, whereas the methylation rate was $91 \%(30 / 33)$ on the promoter region of the NOL4 gene in 
Table III. QMSP results and demographics of the patients with HNSCC.

\begin{tabular}{|c|c|c|c|c|c|c|c|c|c|}
\hline $\begin{array}{l}\text { Tumor } \\
\text { samples }\end{array}$ & IRXI & NOL4 & $\begin{array}{c}\text { Age } \\
\text { (years) }\end{array}$ & Gender & Race & Smoking & Alcohol & $\begin{array}{l}\text { Tumor anatomic } \\
\text { site }\end{array}$ & $\begin{array}{l}\text { Overall } \\
\text { stage }\end{array}$ \\
\hline 1 & $\mathrm{~N}$ & $\mathrm{~N}$ & 67 & M & $\mathrm{C}$ & Yes & Yes & Nasal floor & 2 \\
\hline 2 & $\mathrm{Y}$ & $\mathrm{Y}$ & 57 & M & $\mathrm{C}$ & Yes & Yes & Larynx & 2 \\
\hline 3 & $\mathrm{~N}$ & $\mathrm{~N}$ & 61 & M & $\mathrm{C}$ & No & No & Neck & 3 \\
\hline 4 & $\mathrm{Y}$ & $\mathrm{Y}$ & 60 & $\mathrm{~F}$ & $\mathrm{C}$ & Yes & Yes & Larynx & 4 \\
\hline 5 & $\mathrm{Y}$ & $\mathrm{Y}$ & 55 & M & A & Yes & Yes & Larynx & 2 \\
\hline 6 & $\mathrm{Y}$ & $\mathrm{Y}$ & 54 & M & $\mathrm{C}$ & No & Yes & Oropharynx & 4 \\
\hline 7 & $\mathrm{Y}$ & $\mathrm{N}$ & 64 & M & A & Yes & Yes & Hypopharynx & 3 \\
\hline 8 & $\mathrm{Y}$ & $\mathrm{Y}$ & 55 & $\mathrm{~F}$ & A & Yes & No & Oral cavity & 1 \\
\hline 9 & $\mathrm{~N}$ & $\mathrm{Y}$ & 80 & M & $\mathrm{C}$ & Yes & No & Oral cavity & NA \\
\hline 10 & $\mathrm{Y}$ & $\mathrm{Y}$ & 54 & $\mathrm{~F}$ & $\mathrm{C}$ & No & & Oral cavity & 4 \\
\hline 11 & $\mathrm{Y}$ & $\mathrm{Y}$ & 62 & M & $\mathrm{C}$ & Yes & Yes & Oropharynx & 4 \\
\hline 12 & $\mathrm{Y}$ & $\mathrm{Y}$ & 72 & M & $\mathrm{C}$ & Yes & Yes & Hypopharynx & 3 \\
\hline 13 & $\mathrm{Y}$ & $\mathrm{Y}$ & 42 & M & $\mathrm{C}$ & Yes & No & Larynx & 2 \\
\hline 14 & $\mathrm{Y}$ & $\mathrm{Y}$ & 66 & $\mathrm{M}$ & $\mathrm{C}$ & Yes & No & Oropharynx & 4 \\
\hline 15 & $\mathrm{Y}$ & $\mathrm{Y}$ & 74 & M & $\mathrm{C}$ & Yes & & Larynx & 2 \\
\hline 16 & $\mathrm{Y}$ & $\mathrm{Y}$ & 58 & M & A & Yes & Yes & Oropharynx & 4 \\
\hline 17 & $\mathrm{Y}$ & $\mathrm{Y}$ & 56 & $\mathrm{~F}$ & $\mathrm{C}$ & Yes & Yes & Oral cavity & 2 \\
\hline 18 & $\mathrm{Y}$ & $\mathrm{Y}$ & 43 & M & $\mathrm{C}$ & Yes & Yes & Oropharynx & 4 \\
\hline 19 & $\mathrm{Y}$ & $\mathrm{Y}$ & 68 & M & $\mathrm{C}$ & Yes & Yes & Oropharynx & 4 \\
\hline 20 & $\mathrm{Y}$ & $\mathrm{Y}$ & 63 & M & A & Yes & & Oral cavity & NA \\
\hline 21 & $\mathrm{Y}$ & $\mathrm{Y}$ & 64 & $\mathrm{~F}$ & $\mathrm{C}$ & No & Yes & Oral cavity & 3 \\
\hline 22 & $\mathrm{~N}$ & $\mathrm{Y}$ & 88 & M & $\mathrm{C}$ & Yes & Yes & Oral cavity & NA \\
\hline 23 & $\mathrm{Y}$ & $\mathrm{Y}$ & 42 & $\mathrm{M}$ & $\mathrm{C}$ & Yes & No & Oral cavity & 3 \\
\hline 24 & $\mathrm{Y}$ & $\mathrm{Y}$ & 51 & M & $\mathrm{C}$ & Yes & Yes & Larynx & 4 \\
\hline 25 & $\mathrm{Y}$ & $\mathrm{Y}$ & 80 & M & $\mathrm{C}$ & No & Yes & Neck & NA \\
\hline 26 & $\mathrm{Y}$ & $\mathrm{Y}$ & 58 & M & $\mathrm{C}$ & Yes & Yes & Larynx & 3 \\
\hline 27 & $\mathrm{Y}$ & $\mathrm{Y}$ & 71 & M & $\mathrm{C}$ & Yes & Yes & Neck & NA \\
\hline 28 & $\mathrm{Y}$ & $\mathrm{Y}$ & 48 & M & $\mathrm{C}$ & Yes & Yes & Oropharynx & 4 \\
\hline 29 & $\mathrm{Y}$ & $\mathrm{Y}$ & 61 & M & $\mathrm{C}$ & Yes & No & Maxillary sinus & 1 \\
\hline 30 & $\mathrm{Y}$ & $\mathrm{Y}$ & 77 & M & $\mathrm{C}$ & No & No & Salivary gland & NA \\
\hline 31 & $\mathrm{Y}$ & $\mathrm{Y}$ & 67 & M & $\mathrm{C}$ & & & Larynx & 3 \\
\hline 32 & $\mathrm{Y}$ & $\mathrm{Y}$ & 36 & M & $\mathrm{C}$ & Yes & No & Oral cavity & 4 \\
\hline 33 & $\mathrm{Y}$ & $\mathrm{Y}$ & 74 & $\mathrm{~F}$ & $\mathrm{C}$ & No & Yes & Maxillary sinus & 4 \\
\hline
\end{tabular}

M, male; F, female; C, Caucasian; A, African; Y, methylated; N, unmethylated; QMSP, real-time quantitative methylation-specific PCR; HNSCC, head and neck squamous cell carcinoma; IRX1, iroquois homeobox 1; NOL4, nucleolar protein 4; NA, not available.

HNSCC tumor samples showing high methylation values are $79 \%(26 / 33)$ of the patients between 10 and $100 \%$. The IRXI gene [10/14 (71\%), 9/16 (56.25\%) and 29/33 (88\%)] demonstrated varying degrees of methylation on their promoter regions in normal mucosa, normal salivary rinses and HNSCC tumor samples, respectively (Fig. 1). Although normal salivary methylation rate was observed as high, IRXI methylation values were $<1 \%$ in normal salivary rinses and were mostly $(8 / 14,57 \%)$ between 0.1 and $10 \%$ in normal mucosal samples indicating a very strong marker which may define HNSCC tumor tissues as a potential biomarker (Fig. 1).

\section{Discussion}

In the present study, we investigated methylation status of the promoter regions of 12 genes by bisulfite modification, bisulfite sequencing and QMSP techniques. Only two of them (IRXI and NOL4) showed methylation in their CpG islands located on promoter region of these genes, indicating a characteristic of a biomarker molecule. NOL4 gene encoding a nucleolar protein which is expressed predominantly in brain and testis, was identified by Ueki et al (31) and there is only one study showing high methylation status of 20 patients with cervical 
Table IV. Information regarding candidate tumor suppressor genes and the bisulfite sequencing results.

\begin{tabular}{llllll}
\hline Gene ref. ID & \multicolumn{1}{c}{ Chromosomal location } & $\begin{array}{c}\text { Candidate } \\
\text { TSGs }\end{array}$ & $\begin{array}{c}\text { Normal salivary } \\
\text { rinses n }(\%)\end{array}$ & $\begin{array}{c}\text { HNSCC } \\
\text { tissue n }(\%)\end{array}$ & $\begin{array}{c}\text { HNSCC cell } \\
\text { lines n }(\%)\end{array}$ \\
\hline NM_052953 & chr3:26,664,300-26,752,265 & LRRC3B & $1 / 3(33)$ & $3 / 4(75)$ & $4 / 4(100)$ \\
NM_003787 & chr18:31,431,070-31,803,446 & NOL 4 & $\mathbf{0 / 6}(\mathbf{0})$ & $\mathbf{6 / 6}(\mathbf{1 0 0})$ & $\mathbf{4 / 4}(\mathbf{1 0 0})$ \\
NM_001037802 & chr18:44,757,495-44,775,554 & FUSSEL18 & $5 / 8(62.5)$ & $4 / 7(57)$ & $3 / 4(75)$ \\
NM_001005463 & chr10:131,633,547-131,762,091 & EBF3 & $2 / 4(50)$ & $1 / 3(33)$ & $3 / 4(75)$ \\
NM_001485 & chr2:237,074,307-237,076,652 & GBX2 & $3 / 5(60)$ & $4 / 6(67)$ & $4 / 4(100)$ \\
NM_024337 & chr5:3,596,168-3,601,517 & IRX1 & $\mathbf{0 / 6}(\mathbf{0})$ & $\mathbf{6 / 6}(\mathbf{1 0 0})$ & $\mathbf{4 / 4}(\mathbf{1 0 0 )})$ \\
NM_005519 & chr10:124,907,638-124,910,188 & HMX2 & $2 / 4(50)$ & $1 / 3(33)$ & $4 / 4(100)$ \\
NM_145913 & chr12:101,549,994-101,604,016 & SLC5A8 & $3 / 5(60)$ & $2 / 3(67)$ & $2 / 2(100)$ \\
NM_006640 & $c h r 17: 75,315,597-75,496,678$ & SEPT9 & $4 / 7(57)$ & $2 / 3(67)$ & $2 / 4(50)$ \\
NM_006492 & chr1:110,602,997-110,613,322 & ALX3 & $1 / 3(33)$ & $0 / 3(0)$ & $3 / 4(75)$ \\
NM_003955 & chr17:76,352,859-76,356,158 & SOCS3 & $0 / 8(0)$ & $0 / 8(0)$ & $1 / 2(50)$ \\
NM_014368 & chr9:124,964,858-124,991,019 & LHX6 & $0 / 8(0)$ & $0 / 8(0)$ & $1 / 1(100)$ \\
\hline
\end{tabular}

HNSCC, head and neck squamous cell carcinoma; LRRC3B, leucine rich repeat containing 3B; NOL4, nucleolar protein 4; FUSSEL18, functional smad-suppressing element on chromosome 18; $E B F 3$, early B-cell factor 3; GBX2, gastrulation brain homeobox 2; IRX1, iroquois homeobox 1; HMX2, H6 family homeobox 2; SLC5A8, sodium-coupled monocarboxylate transporter 1; SEPT9, septin 9; ALX3, ALX homeobox 3; SOCS3, suppressor of cytokine signaling 3; LHX6, LIM homeobox 6.

cancer by MethyLight assays (32) in concordance with our results.

The IRXI gene is a member of the iroquois homeobox gene family and plays a role during pattern formation of vertebrate embryos. In published literature, there are only four studies investigating the effects of epigenetically silencing IRXI gene, in the patients with gastric cancer (33) and the studies of Bennett et al with HNSCC (7,8,34). Bennett et al (7) reported an association between the HNSCC and hypermethylation of IRXI in accordance with our results, and four other genes (FUSSEL18, EBF3, SLC5A8 and SEPT9), but not SLC5A8; we did not find any methylated $\mathrm{CpG}$ on the promoter regions of the last five genes. In two other studies, Bennett et al also showed the association between IRXI methylation and recurrence and between four other genes and clinicopathological parameters such as HPV status, alcohol and tobacco usage (8) and they investigated the interactions with some molecules of the TGF- $\beta$ pathway, and their transcriptional inactivation by methylation in HNSCC caused the decrease in apoptosis and differentiation, and increased proliferation (34). In the present study, we only observed the methylation of the IRXI gene which was the one of the five frequently methylated genes identified by Restriction Landmark Genomic Scanning (RLGS) method in metastatic HNSCC samples compared to primary tumors. Mass array methylation (7) and COBRA (8) analysis were used in fresh/paraffin-embeded HNSCC tumors and matched normal mucosa samples in the previous studies of Bennett et al $(7,8)$. We screened the methylated CpG islands on the promoter regions of these genes by bisulfite sequencing using frozen HNSCC tumors, HNSCC cell lines and normal salivary rinses in order to select the genes that have the methylated $\mathrm{CpG}$ islands on their promoter regions in tumor samples but no methylation in normal mucosal and normal salivary rinse samples. Then, the methylation levels were measured by
QMSP technique in 33 HNSCC tumors, 16 salivary rinses and 14 normal mucosa as reported in our previous study (35). Our aim was to find a cancer-specific biomarker and to detect the tumor tissues in salivary rinses of the patients earlier and to screen the normal population. In addition, in a previous study (34), tonsillar carcinoma samples were used, whereas we quantified the methylation in the primary tumors of the oral cavity, oropharynx, hypopharynx, larynx, maxillary sinus, nasal floor and unknown primary/neck. Therefore, discrepant observations between these studies by Bennett et al $(7,8,34)$ and our data may be due to confounding factors including anatomic site, methodology and sampling method. Therefore, the four other genes described by Bennett et al $(7,8)$, may not be good biomarker candidates in salivary rinse samples despite being differentially methylated in primary tumor samples. The present study is the first to investigate the methylation levels of NOL4 gene and to show high methylation in the patients with HNSCC by QMSP technique.

In addition, it would be helpful to increase sample size to facilitate a more precise determination of accuracy of these biomarkers in detection of the disease and to evaluate the association of the results with the clinical parameters of the disease. These newly identified silenced genes here remain to be tested in saliva, serum or plasma samples from HNSCC patients in a larger sample size.

\section{Acknowledgements}

This study was supported by the National Cancer Institute SPORE (5P50CA096784-05) and the Scientific Research Projects Coordination Unit of Istanbul University (UDP30980). This study/analysis is based on a web database application provided by Research Information Technology Systems (RITS)-https://www.rits.onc.jhmi.edu/. 


\section{References}

1. Jemal A, Siegel R, Ward E, Murray T, Xu J, Smigal C and Thun MJ: Cancer statistics, 2006. CA Cancer J Clin 56: 106-130, 2006.

2. Baylin SB, Herman JG, Graff JR, Vertino PM and Issa JP: Alterations in DNA methylation: a fundamental aspect of neoplasia. Adv Cancer Res 72: 141-196, 1998.

3. Dulaimi E, Hillinck J, Ibanez de Caceres I, Al-Saleem T and Cairns P: Tumor suppressor gene promoter hypermethylation in serum of breast cancer patients. Clin Cancer Res 10: 6189-6193, 2004.

4. Leonhardt $\mathrm{H}$ and Cardoso MC: DNA methylation, nuclear structure, gene expression and cancer. J Cell Biochem Suppl 35: $78-83,2000$

5. Herman JG and Baylin SB: Gene silencing in cancer in association with promoter hypermethylation. N Engl J Med 349: 2042-2054, 2003.

6. Yamashita K, Upadhyay S, Osada M, et al: Pharmacologic unmasking of epigenetically silenced tumor suppressor genes in esophageal squamous cell carcinoma. Cancer Cell 2: 485-495, 2002.

7. Bennett KL, Karpenko M, Lin MT, et al: Frequently methylated tumor suppressor genes in head and neck squamous cell carcinoma. Cancer Res 68: 4494-4499, 2008.

8. Bennett KL, Lee W, Lamarre E, et al: HPV status-independent association of alcohol and tobacco exposure or prior radiation therapy with promoter methylation of FUSSEL18, EBF3, IRXI and $S E P T 9$, but not $S L C 5 A 8$, in head and neck squamous cell carcinomas. Genes Chromosomes Cancer 49: 319-326, 2010.

9. Estécio MR, Youssef EM, Rahal P, et al: LHX6 is a sensitive methylation marker in head and neck carcinomas. Oncogene 25: 5018-5026, 2006.

10. Pierconti F, Martini M, Pinto F, et al: Epigenetic silencing of SOCS3 identifies a subset of prostate cancer with an aggressive behavior. Prostate 71: 318-325, 2011

11. Isomoto $\mathrm{H}$ : Epigenetic alterations in cholangiocarcinomasustained IL-6/STAT3 signaling in cholangio- carcinoma due to SOCS3 epigenetic silencing. Digestion 79 (Suppl 1): 2-8, 2009.

12. Fourouclas N, Li J, Gilby DC, et al: Methylation of the suppressor of cytokine signaling 3 gene (SOCS3) in myeloproliferative disorders. Haematologica 93: 1635-1644, 2008.

13. Martini M, Pallini R, Luongo G, Cenci T, Lucantoni $C$ and Larocca LM: Prognostic relevance of SOCS3 hypermethylation in patients with glioblastoma multiforme. Int J Cancer 123 2955-2960, 2008.

14. Weber A, Hengge UR, Bardenheuer W, et al: SOCS-3 is frequently methylated in head and neck squamous cell carcinoma and its precursor lesions and causes growth inhibition. Oncogene 24: 6699-6708, 2005.

15. Thangaraju M, Gopal E, Martin PM, Ananth S, Smith SB, Prasad PD, Sterneck E and Ganapathy V: SLC5A8 triggers tumor cell apoptosis through pyruvate-dependent inhibition of histone deacetylases. Cancer Res 66: 11560-11564, 2006.

16. Zhao LY, Niu Y, Santiago A, Liu J, Albert SH, Robertson KD and Liao D: An EBF3-mediated transcriptional program that induces cell cycle arrest and apoptosis. Cancer Res 66: 94459452, 2006.

17. Yu YY, Ji J, Lu Y, Bu L, Liu BY, Zhu ZG and Lin YZ: Highresolution analysis of chromosome 5 and identification of candidate genes in gastric cancer. Zhonghua Zhong Liu Za Zhi 28: 84-87, 2006 (In Chinese).
18. Jönsson G, Staaf J, Olsson E, et al: High-resolution genomic profiles of breast cancer cell lines assessed by tiling BAC array comparative genomic hybridization. Genes Chromosomes Cancer 46: 543-558, 2007.

19. Burrows JF, Chanduloy S, McIlhatton MA, et al: Altered expression of the septin gene, SEPT9, in ovarian neoplasia. J Pathol 201: 581-588, 2003.

20. Amir S, Wang R, Matzkin H, Simons JW and Mabjeesh NJ: MSF-A interacts with hypoxia-inducible factor-1 $\alpha$ and augments hypoxia-inducible factor transcriptional activation to affect tumorigenicity and angiogenesis. Cancer Res 66: 856-866, 2006.

21. Endo S, Zeng Q, Burke NA, et al: TGF- $\alpha$ antisense gene therapy inhibits head and neck squamous cell carcinoma growth in vivo. Gene Ther 7: 1906-1914, 2000.

22. Le QT, Kong C, Lavori PW, et al: Expression and prognostic significance of a panel of tissue hypoxia markers in head-andneck squamous cell carcinomas. Int J Radiat Oncol Biol Phys 69: 167-175, 2007.

23. Sánchez-Elsner T, Botella LM, Velasco B, Corbí A, Attisano L and Bernabéu C: Synergistic cooperation between hypoxia and transforming growth factor- $\beta$ pathways on human vascular endothelial growth factor gene expression. J Biol Chem 276: 38527-38535, 2001.

24. Bernard PS and Wittwer CT: Real-time PCR technology for cancer diagnostics. Clin Chem 48: 1178-1185, 2002.

25. Eads CA, Danenberg KD, Kawakami K, et al: MethyLight: a high-throughput assay to measure DNA methylation. Nucleic Acids Res 28: E32, 2000

26. Cottrell SE and Laird PW: Sensitive detection of DNA methylation. Ann NY Acad Sci 983: 120-130, 2003.

27. Jerónimo C, Usadel H, Henrique R, Oliveira J, Lopes C, Nelson WG and Sidransky D: Quantitation of GSTP1 methylation in non-neoplastic prostatic tissue and organ-confined prostate adenocarcinoma. J Natl Cancer Inst 93: 1747-1752, 2001.

28. Tokumaru Y, Yamashita K, Osada M, et al: Inverse correlation between cyclin A1 hypermethylation and p53 mutation in head and neck cancer identified by reversal of epigenetic silencing. Cancer Res 64: 5982-5987, 2004.

29. Li LC and Dahiya R: MethPrimer: designing primers for methylation PCRs. Bioinformatics 18: 1427-1431, 2002.

30. Park HL, Kim MS, Yamashita K, et al: DCC promoter hypermethylation in esophageal squamous cell carcinoma. Int $\mathrm{J}$ Cancer 122: 2498-2502, 2008.

31. Ueki N, Kondo M, Seki N, Yano K, Oda T, Masuho Y and Muramatsu M: NOLP: identification of a novel human nucleolar protein and determination of sequence requirements for its nucleolar localization. Biochem Biophys Res Commun 252: 97-102, 1998.

32. Wang SS, Smiraglia DJ, Wu YZ, et al: Identification of novel methylation markers in cervical cancer using restriction landmark genomic scanning. Cancer Res 68: 2489-2497, 2008.

33. Guo X, Liu W, Pan Y, et al: Homeobox gene IRX1 is a tumor suppressor gene in gastric carcinoma. Oncogene 29: 3908-3920, 2010.

34. Bennett KL, Romigh T and Eng C: Disruption of transforming growth factor- $\beta$ signaling by five frequently methylated genes leads to head and neck squamous cell carcinoma pathogenesis. Cancer Res 69: 9301-9305, 2009.

35. Demokan S, Chuang AY, Chang X, et al: Identification of guanine nucleotide-binding protein $\gamma-7$ as an epigenetically silenced gene in head and neck cancer by gene expression profiling. Int J Oncol 42: 1427-1436, 2013. 